\title{
Success of Professional Activities of Representatives of Humanitarian Professions
}

\author{
Alexey Yurievich Kodzhaspirov ${ }^{1 *}$, Lyudmila Viktorovna Polyakova ${ }^{2}$ \\ ${ }^{1}$ Moscow State Psychological and Pedagogical University, Moscow, Russia \\ ${ }^{2}$ Moscow State Pedagogical University, Moscow, Russia
}

\begin{abstract}
The study reveals the relationship between the success of professional activity with the personal characteristics of representatives of humanitarian professions. The following diagnostic means were used to establish the relationship of personal characteristics with the successful development of professional skills of students studying humanities: Methodology "Personality traits" (J. Barrett), Diagnostics of the structure of signal systems (E. F. Zeer, A. M. Pavlova), Methodology express diagnostics of the characteristics of the nervous system by psychomotor indicators E. P. Iliin. Based on the analysis of psychological and pedagogical literature and the study, the authors conclude that professional success in the humanitarian professions is associated with personality traits: sociability, focus on facts, as well as mobility of the nervous system. The absence of these traits negatively affects the effectiveness of professional activity.
\end{abstract}

\section{Page layout}

The problem of professional success attracts philosophers, educators, psychologists, and public figures. However, there are different understanding of this phenomenon.

The formation of the concept of the phenomenon of success in professional activity is of great importance in connection with the solution of several problems that face modern psychology of work. Based on the assessment of the success of professional activity, conclusions are drawn regarding a specific subject of labor, as well as groups of subjects of labor activity - organizations, work collectives and production teams. The understanding of the nature of a person's success can motivate a person to improve their own professional qualities and characteristics or change their place of work.

\section{Methods}

The problem of human success was considered in the framework of biological theories focused on talent and giftedness. This is the result of genetically integrated human characteristics, such as abilities and intelligence. R. Sternberg in the triarchic theory of intelligence points to the relationship of intelligence with the success of a person throughout their life cycle. The author defines success as the ability to achieve a high level of personal

* Corresponding author: teledov@list.ru 
standards, which are determined by the social context, linking this ability with creative, analytical and practical abilities [1].

In the scientific literature, there is an opinion that in relation to work activities, the categories of "success" and "productivity" are synonyms. However, these characteristics vary significantly as V. D. Nebylitsin, N. I. Maisel, and B. M. Teplov note [2].

The success of work can be considered as a characteristic, which includes the level of productivity, quality of labor and the accuracy of actions. When assessing the success of work, the physiological costs necessary to solve various professional issues are considered. The success of work is associated with the motivational, intellectual, and affective-volitional spheres of the personality, and depends on several psychophysiological qualities and characteristics [1].

Professional success is seen as a person's popularity in professional activity; recognition as "significant others", where the awareness of the importance of the subject for an authoritative person acts as a motivating force; as self-determination, the necessary element of which is self-determination, and as the result a valuable personal experience; recognition in which both outcome and process are important.

Based on the results of summarizing the theoretical positions of different authors, we can agree that professional success is a kind of property of the "man - profession" metasystem, which characterizes the subjects of labor, reflecting its compliance with the requirements of professional activity, job satisfaction, and the desire for further professional fulfillment in this field [2-5].

Professional success depends on the professional competence of a specialist and on professionally important personal qualities (PIPQ), which include dynamic personality traits, mental and psychomotor properties, and physical qualities. These qualities must meet the requirements of the profession and contribute to its effective development.

V. D. Shadrikov argues that PIPQ are internal conditions through which external influences and activity requirements are refracted, this is a fundamental factor in the formation of the psychological system of activity [6]. E. P. Ermolaeva defines PIPQ as a psychological potential for the formation of knowledge and skills, which are the criterion and resource necessary for the development of professional competence [7, 8].

E. S. Shelepova conditions these qualities as elements of professional suitability and as properties that are necessary for a specialist to successfully solve professional problems, situations, and difficulties. Among them are many different qualities - from natural inclinations to professional knowledge gained during vocational learning and self-learning, personality traits (motivation, orientation, semantic sphere, character), psychophysiological characteristics (temperament, HNF (Higher Nervous Function) features), mental processes (memory, attention, thinking, imagination), and regarding specific types of activity, even the anatomical and morphological properties of man [9].

Among the qualities that contribute to success in a professional activity most often include focus, ability to communicate with people, physical endurance, ability to predict the future, flexibility, and ability to persuade.

M. A. Dmitrieva and A. A. Krylov introduced the concept "professionally important properties" that include:

- individually typological (individual style of activity),

- $\quad$ sensory and perceptual (especially sensation and perception),

- $\quad$ attenionic (properties of attention),

- psychomotor,

- mnemonic (memory properties),

- immunity (properties of imagination),

- mental, volitional properties and intellectual skills [10]. 
B. A. Dushkov, A. V. Korolev, and B. A. Smirnov argue that it is not only the individual personality traits that are essential for mastering a profession, but also physical qualities that meet the conditions for successful mastering of a particular profession [11, 12].

The purpose of the study is to establish the relationship of personal characteristics with the successful development of professional skills of students studying the humanities.

The object of the study is the success of the professional activities of representatives of the humanitarian professions.

The subject of the study is personality traits that determine the success of representatives of the humanitarian professions.

The hypothesis of the study: in the humanities, factors determining success can be personality traits: a high level of sociability, focus on facts, and mobility of the nervous system.

The following methods were used in an empirical study: Methodology "Personality traits" (J. Barrett), Diagnostics of the structure of signaling systems (E. F. Zeer, A. M. Pavlova) [13, 14], Diagnostics of communicative tolerance (V. V. Boyko), Methodology express diagnostics of the characteristics of the nervous system by psychomotor indicators E. P. Iliin [15].

The study involved 60 representatives of humanitarian professions, teachers and psychologists who work in the education system from 27 to 42 years old.

Diagnostic results using the methodology "Personality Traits"

The study revealed that the most pronounced personality traits among the study participants were sociability (38.23), confidence (40.73), focus on facts (40.45), and discretion (34.90). These can be considered typical of representatives of the humanitarian professions who participated in the study.

The lowest level of severity are indicators of individualism (20.38), passivity (19.20), focus on imagination (20.33), as well as indicators of spontaneity (34.90).

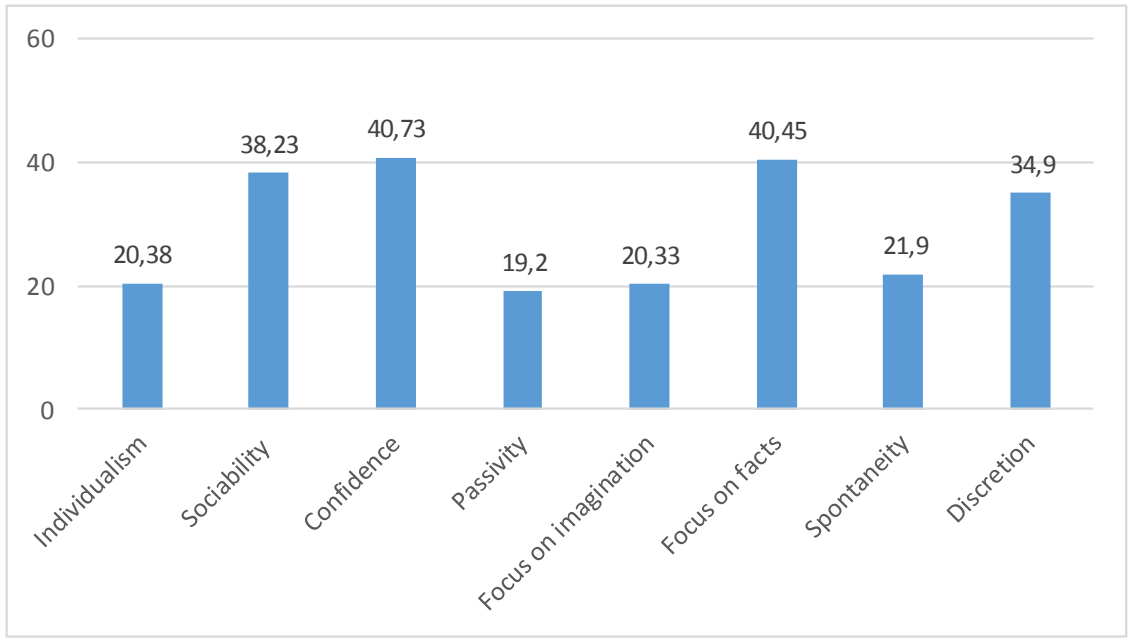

Fig. 1. The ratio of the average values of indicators of formation of personality traits

Thus, based on the results of diagnosing the personality formation of representatives of the humanitarian professions, it can be stated that the following personality traits are characteristic of this group of respondents: dominance, orientation to support one's neighbor, stubbornness, and determination.

The results of a psychodiagnostic study of the signs of the signal system allow us to state a moderate level of manifestation of such signal subsystems as "metaphorization" (3.78), 
"imagery" (3.75), "symbolization" (3.83), and "verbalization" (3, 83), as well as the expressed level of signaling systems such as "abstraction" (6.05), "reflexivity" (6.05), as well as "hand skills" (5.75).

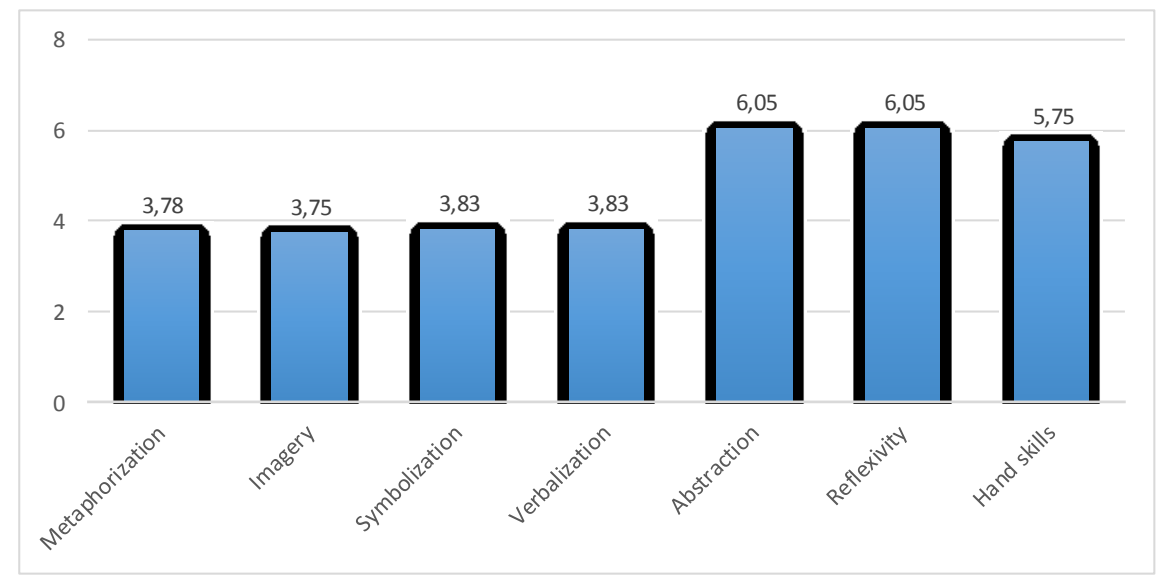

Fig. 2. The ratio of the average values of the indicators of the structure of signal systems

Therefore, the subjects are able to generalize the concrete, go into the field of abstraction, they have a sufficiently high level of development of the ability to hold the same information for a long time, tend to think through their own actions, and have a high level of ability to manually manipulate objects.

The analysis of the results of the study of communicative tolerance suggests that most of the individuals participating in the study are characterized by moderate values of various aspects of communicative tolerance. Subjects can understand and accept the personality of another person and they are not inclined to use themselves as a standard for evaluating other people. They lack a pronounced categorical assessment of other people. In addition, it should be noted a low level of intolerance to the uncomfortable conditions of other people. At the same time, there is a tendency to adjust other participants for themselves, as well as a desire to remake or re-educate a communication partner. However, this trend does not have a high level of expression and does not negatively affect communication and professional activity that took part in the study. 


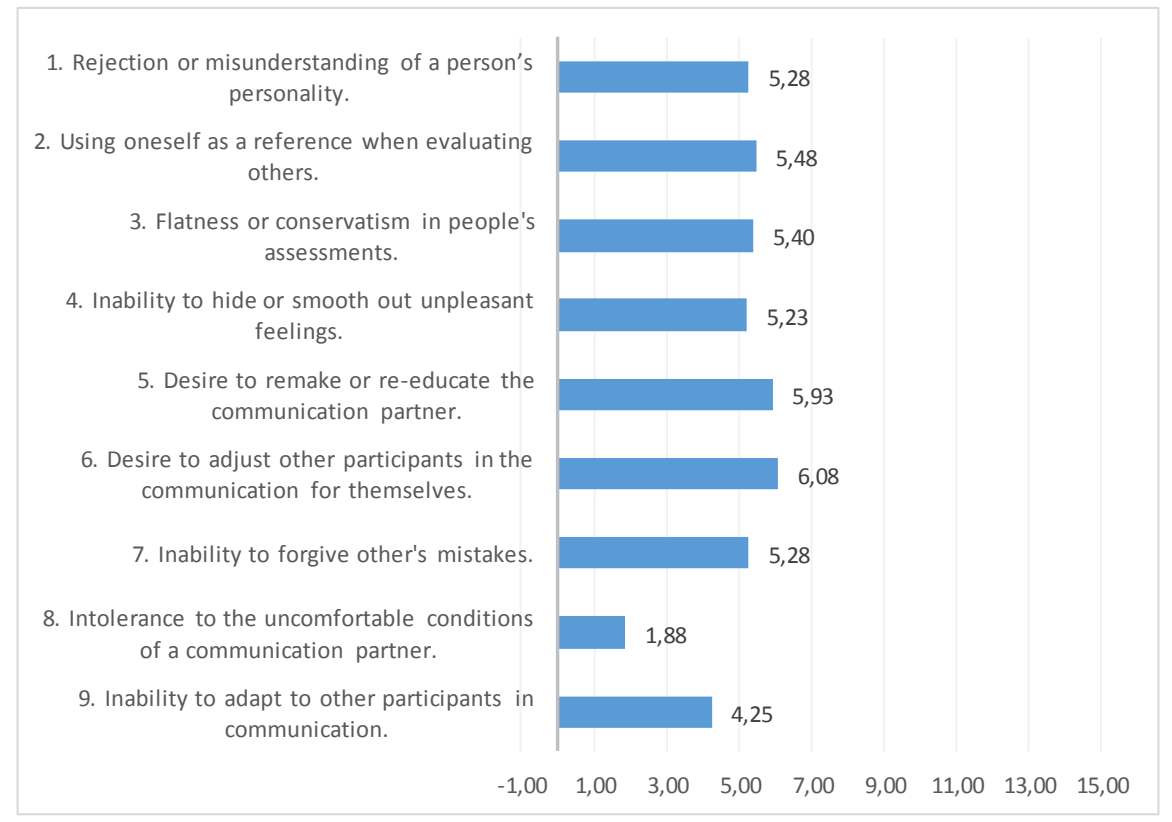

Fig. 3. The ratio of the average values of indicators of communicative tolerance

The results of calculating the generalized indicator of communicative tolerance suggest that the majority of study participants $(52.5 \%)$ have a high degree of tolerance, and an average level of communicative tolerance is characteristic of $47.5 \%$ of respondents.

Diagnosis of the features of the manifestation of properties of the nervous system allows us to distinguish the following properties: the majority of respondents are characterized by a mobile nervous system (37.5\%). Supermobile type of a nervous system was detected in four study participants (10\%). An inert nervous system is diagnosed in $22.5 \%$ of humanitarian professions.

To determine the characteristics of success, the submitted documents were studied. The emphasis was on the presence/absence of disciplinary sanctions, rewards, bonuses, as well as awards of methodological developments, student performance or the results of psychological influences.

The results allow us to conclude that the majority of study participants (62.5\%) have an average level of success in performing activities. An exceptionally high level of effectiveness was found in the ratio of $17.5 \%$ of the participants, while a moderate level of success was found in $20 \%$ of the study participants.

The next stage of the study is the correlation analysis procedure using Spearman's rank correlation coefficient.

During the correlation analysis, several correlations of indicators of abilities and personal characteristics and indicators of success of labor activity were revealed. It was determined that the success indicators of professional activity correlate with indicators of sociability $(\mathrm{r}=$ $0.76)$, focus on facts $(r=0.45)$, discretion $(r=0.55)$, imagery $(r=0.32)$, symbolization $(r=$ $0.38)$, reflexivity $(\mathrm{r}=0.41)$, and also an indicator of the formation of properties of the nervous system $(r=0.69)$.

\section{Conclusion}


The theoretical analysis of psychological and pedagogical literature made it possible to define professional success as a property of the metasystem "man - profession", which characterizes the subjects of labor, reflecting its compliance with the requirements of professional activity, job satisfaction, and the desire for further professional self-realization in this area. Professional success depends not only on professional competence, but also on PIPQ.

The analysis of the results allows us to state that the formation of professional success among representatives of the humanitarian professions is facilitated by a high level of sociability, focus on facts, and a high level of mobility of the nervous system.

On the other hand, specialists who have a high level of imagery, reflexivity, and symbolization will most likely have a low level of professional success. This conclusion is relative and needs a deeper study.

\section{References}

1. R. Sternberg, Intellekt uspekha [Successful intelligence] (Popurri, Minsk, 2015)

2. V.I. Reutova, Psychopedagogy in Law Enforcement 2(73) (2018)

3. Iu.A. Karacharova, Aktualnye voprosy sovremennoi nauki 6-3 (2009)

4. L. Hjelle, D. Ziegler, Teorii lichnosti [Personality Theories] (Piter Press, St. Petersburg, 2017)

5. A.V. Khutorskoi, Metapredmetnyi podkhod v obuchenii: Nauchno-metodicheskoe posobie. 2-e izd., pererab. i dop. [Metasubject approach in Learning: a Study guide. 2nd edition, Revised and Added] (Izdatelstvo «Eidos», Moscow, 2016)

6. V.D. Shadrikov sikhologiia deiatelnosti i sposobnosti cheloveka: Ucheb. posobie [Psychology of Human Activity and Ability: a Study Guide] (Izdatelstvo «Institut psikhologii RAN», Moscow, 2013)

7. G.V. Bezuleva, Professionalnoe obrazovanie 12, 25-30 (2005)

8. L.G. Dikaia, A.L. Zhuravlev, Lichnost professionala $v$ sovremennom mire [The Personality of a Professional in the Modern World] (Izd-vo «Institut psikhologii RAN», Moscow, 2014)

9. 9.E.S. Shelepova, O probleme professionalno vazhnykh kachestv subekta trudovoi deiatelnosti [On the Issue of Professionally Important Qualities of a Subject of Labor Activity] (TGU, Tver, 2007)

10. M.A. Dmitrieva, A.A. Krylov, Psikhologiia truda i inzhenernaia psikhologiia [Labor Psychology and Engineering Psychology] (Izdatelstvo Leningradskogo Universiteta, Leningrad, 1979)

11. B.A. Dushkov, A.V. Korolev, B.A. Smirnov, Psikhologiia truda, professionalnoi informatsionnoi i organizatsionnoi deiatelnosti [Psychology of Labor, Professional Information and Organizational Activities] (Fond "Mir", Moscow, 2005)

12. T.V. Kornilova, S.D. Smirnov, Metodologicheskie osnovy psikhologii: uchebnik dlia vuzov [Methodological Foundations of Psychology: a Textbook for Universities] (Yurait, Moscow, 2013)

13. Ia.S. Suntsova, Diagnostika professionalnogo samoopredeleniia: ucheb.-metod.posobie [Diagnosis of Professional Self-determination: a Study Guide] (Izdatelstvo «Udmurtskii universitet», Izhevsk, 2009)

14. E.F. Zeer, Vysshee obrazovanie v Rossii 4, 23-29 (2005) 
15. E.P. Iliin, Differentsialnaia psikhologiia professionalnoi deiatelnosti [Differential Psychology of Professional Activity] (Piter, St. Petersburg, 2008). 